\title{
ПОНЯТІЙНО-ПРАВОВЕ МИСЛЕННЯ У СТАРОДАВНІЙ ГРЕЦЇ̈: ВІД СОКРАТА ДО ПЛАТОНА
}

\author{
Кучеренко Д. С., Гамбург Л. С.
}

\section{ВСТУП}

Давньогрецька наука розвивалася в особливий, незалежний від інших вид діяльності. Поступово вона переходила до абстрагованих досліджень, у яких готувалися основні форми наукового світогляду. Греко-перські війни (500-449 до н. е.), боротьба між давньогрецькими містами, а у містах - між окремими родами й особами похитнули значення всього усталеного у сфері права, порядку, звичаю. Могутнє піднесення національної самосвідомості давніх греків призвело до перевороту всієї дійсності, до якого була дотична і наука. Велику ціну за таких умов здобула особистість, більш ясно проявилося значення власного досвіду та самостійних роздумів. За таких умов в особі Сократа людський розум вперше у Європі починає мислити логічно. Сократ своїм розумінням істини у поняттях підняв проблематику пізнання на новий рівень, зробивши предметом філософського пізнання власне знання. Він першим підніс знання до рівня понять і звернув увагу на те, що знання немає без поняття. Запропонована Сократом діалогічна форма пізнання стала першим універсальним філософським і юридичним методом пізнання у європейській традиції. Філософи сократичних шкіл, хоч і продовжили деякі ідеї Сократа, проте не пішли за ним у його беззастережній критиці софістів. Роботу Сократа щодо дослідження понять продовжив його учень Платон. Він намагається подолати суб'єктивізм теорії пізнання софістів і досягнути правильного, для всіх єдиного об'єктивного знання. Ця робота із поняттями, встановлення родо-видових відношень між ними, здійснювана уперше в історії мислення Платоном і його учнями, отримала назву діалектики. Дослідження показало, що Платон за допомогою діалектики поєднав метафізичну та логічну частини пізнання у «теорію ідей», що дозволило класифікувати поняття. Надалі це сприяло виокремленню науки від філософії, становленню видів наукового знання, зокрема науки права.

\section{1. Сократ і сократичні школи}

Одним із основних досягнень Давньої Греції М. Вебер назвав відкриття поняття як одного із найвеличніших засобів будьякого наукового пізнання й усвідомлення значення цього відкриття 800 
й обгрунтовано вказав, що воно у всьому своєму значенні було здійснене Сократом (469-399 до н. е. $)^{1}$. С.М. Трубецькой писав про Сократа: «Он ищет истинных норм теоретической $<\ldots$. > деятельности человека, и притом ищет их в самом разуме человека. Он ставит философии проблему гносеологии (теории познания) <..>. Началом познания, или истинного понимания, является логическое понятие $<\ldots>$. Сократ был основателем логики $<\ldots>$. И вот среди его учеников возникают гносеологические споры о природе понятия в его отношении к действительности, - споры, которые продолжались и в течение Средних веков и перешли в новую философию» ${ }^{2}$. Розвиток цієї концепції продовжили його учні, зокрема Платон, а згодом учень Платона Аристотель. Оскільки від Сократа не залишилося письмових творів, то для більшої об'єктивності звернемося до свідчень про нього, які знаходимо у Ксенофонта, Платона й Аристотеля. У «Метафізиці» Аристотель вказує, що згідно із поглядами Геракліта «все чувственно воспринимаемое постоянно течет; так что если есть знание и разумение чего-то, то помимо чувственно воспринимаемого должны существовать другие сущности (physeis), постоянно пребывающие, ибо о текучем знания не бывает»³. Тоді як теорія пізнання софістів прямо вела до відносності індивідуальної гадки, підгрунтям усієї діяльності Сократа було прагнення до стійкого загальнообов'язкового знання: «Так как и все [философы], и первый еще Сократ, признали, что в природе есть нечто, доступное только мнению, но есть и другое, что может быть усвоено только умом» ${ }^{4}$ Він розвинув свою філософію із наміром дати відсіч вченню софістів, котрі стверджували, що ніякої смислової цілісності та загальних критеріїв у світі не існує, тому, відповідно, не існує й безумовної достовірності знання. Сократ уперше заговорив про предмет знання, розуміючи його не загальностихійно, а саме специфічно-пізнавально. Аристотель продовжує: «Между тем Сократ с полным основанием искал суть вещи, так как он стремился делать умоза-

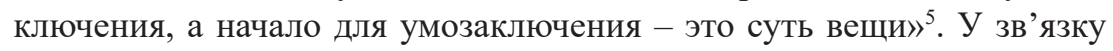
iз тим, що Сократ не знайшов істини у речах, він звернувся до свідомості та пошуку смислів. Дійшовши висновку про неправильність

1 Вебер М. Избранные произведения / пер. с нем.; сост., общ. ред. и послесл. Ю.Н. Давыдова ; предисл. П.П. Гайденко. Москв а: Прогресс, 1990. С. 716.

2 Трубецкой С.Н. История древней философии. Москва, 1906. Ч. І. С. 25.

3 Аристотель. Сочинения : в 4 т. Т. 1 / ред. В.Ф. Асмус. Москва : «Мысль», 1976. С. 327.

4 Маркс К. и Энгельс Ф. Из ранних произведений. Москва : Государственное издательство политической литературы, 1956. С. 159.

5 Аристотель. Сочинения : в 4 т. Т. 1 / ред. В.Ф. Асмус. Москва : «Мысль», 1976. С. 327. 
дослідження причини буття емпіричним шляхом на підставі даних органів відчуттів, Сократ звернувся до філософського розгляду істини буття в абстрактних поняттях. У цьому разі критерієм істини є відповідність того, що пізнається, своєму поняттю. Подібним трактуванням істини у поняттях Сократ зробив предметом філософського пізнання саме знання, у якому досліджується не буття, а знання про нього. Поняття у вченні філософа $є$ не лише результатом розумових зусиль людини, яка пізнає, не лише суб'єктивним феноменом людського мислення, а й певною об'єктивністю розуму, що ним осягається. Сократівська філософія об'єктивного поняття істотно відрізнялася як від уявлень представників попередньої натурфілософії, так і від суб'єктивізму та релятивізму софістів. Якщо до нього філософи і користувалися поняттями, то робили це стихійно. Метод науки як спосіб побудови теоретичного знання шляхом визначення, виведення понять був заснований Сократом. Він перший проголосив, що істина тільки тоді є істиною, коли вона є доведеною. Філософ виходив із того, що основою світу є недоступний відчуттям, але осяжний думкою зв'язок відношень, загальний розумний порядок, який володарює над усім. Якщо ж припустити, розмірковував Сократ, що у світі немає нічого розумного, необхідно визнати, що: «только ум, стало быть, которого нигде нет, по какому-то счастливому случаю, думаешь, ты весь забрал себе, а этот мир, громадный, беспредельный в своей множественности, думаешь, прибывает в таком стройном порядке благодаря какому-то безумию?»6. Він прямо протиставляє гадці знання, причому це знання не є готовим досягненням науки, котре можна передати через навчання, але ідеалом, до якого ще необхідно прагнути шляхом спільної роботи. Оскільки діяльність Сократа була спрямована на спільний пошук істинного знання, вона набула форми діалогу (грец. dialogos - розмова) - бесіди, в якій за допомогою взаємної критики й обміну думками мало бути віднайдене те, що всі зобов'язані визнати. Сократ у бесідах розбиває ті гадки, за якими він спочатку звертається до співрозмовника, а після усунення цих перешкод з усього обговорюваного намагається поступово виокремити спільне положення. Переконаний у тому, що воно може бути віднайдене кожною людиною шляхом серйозних роздумів, він «повиває» думку, що дрімає у розумі, i називає це мистецтво своєю «маєвтикою» (грец. maieutike - повивальне мистецтво): «Самое же великое в нашем искусстве - то, что мы можем разными способами допытываться, рождает ли мысль юноши

\footnotetext{
6 Платон. Сочинения : в 4 т. Т. 2 / под общ. ред. А.Ф. Лосева и В.Ф. Асмуса ; пер. с древнегреч. Санкт-петербург : Изд-во С.-Петерб. ун-та, «Изд-во Олега Абышко», 2007. С. 28. 
ложный призрак или же истинный и полноценный плод. К тому же и со мной получается то же, что с повитухами: сам я в мудрости уже неплоден, и за что меня многие порицали, - что-де я все выспрашиваю у других, а сам никаких ответов никогда не даю, потому что сам никакой мудрости не ведаю, - это правда. < ..> от меня они ничему не могут научиться, просто сами в себе они открывают много прекрасного, если, конечно, имели и производят его на свет. Повития же этого виновники бог и я» ${ }^{7}$. Істинне пізнання згідно із Сократом виходить від бога і приводить до нього: «Они, - говорит Сократ о богах, - вложили в нас разум, посредством которого мы размышляем и вспоминаем о своих чувственных восприятиях, понимаем, на что какая вещь полезна, и придумываем разные средства, благодаря которым пользуемся добром и защищаемся от зла. Боги дали нам также способность речи, которая доставляет нам возможность давать друг другу участие во всех благах путем ученья и самим пользоваться ими сообща с другими, законодательствовать и жить государственной жизнью» ${ }^{8}$.

Сократ під діалектикою розумів метод дослідження понять, спосіб встановлення точних визначень. Визначити яке-небудь поняття для нього означало розкрити зміст цього поняття, віднайти те, що міститься у ньому. За повідомленням Ксенофонта, Сократ був упевнений, що тільки розумна людина здатна «разделяя в теории и на практике предметы по родам, хорошим отдавать предпочтение, а дурных избегать» ${ }^{9}$. Про розуміння Сократом діалектики як методу розділення понять на роди та види свідчить і Платон у діалозі «Софіст»: «Различать все по родам, не принимать один и тот же вид за иной и иной за тот же самый - неужели мы не скажем, что это [предмет] диалектического знания?» ${ }^{10}$. За свідченням Аристотеля, установлення загальних визначень було одним із нововведень Сократа у філософію. У «Метафізиці» він писав: «Сократ < .. > искал общее и первый обратил свою мысль на определения»; «общее не отделил от единичного. И он правильно рассудил, не отделив их» ${ }^{11}$. Метою наукової роботи Сократ вважав «поняття», протиставляючи його одиничним уявленням, які отримуються людиною шляхом індивідуального сприйняття. Він

7 Трубецкой С.Н. История древней философии. Москва, 1906. Ч. І. С. 242-243.

8 Платон. Сочинения : в 4 т. Т. 2 / под общ. ред. А.Ф. Лосева и В.Ф. Асмуса ; пер. с древнегреч. Санкт-Петербург : Изд-во С.-Петерб. ун-та, «Изд-во Олега Абышко», 2007. С. 129.

9 Ксенофонт. Воспоминания о Сократе. Москва : Изд-во «Наука», 1993. С. 141.

10 Платон. Сочинения : в 4 т. Т. 2 / под общ. ред. А.Ф. Лосева и В.Ф. Асмуса ; пер. с древнегреч. Санкт-Петербург : Изд-во С.-Петерб. ун-та, «Изд-во Олега Абышко», 2007. С. 387.

11 Аристотель. Сочинения : в 4 т. Т. 1 / ред. В.Ф. Асмус. Москва : «ысль», 1976. С. 79, 347. 
постійно послуговувався визначеннями та сподівався, що осягне за допомогою загального поняття сутність предмета і закон, який панує над усіма окремими випадками та відношеннями.

Сократичні школи (Мегарська, Кінічна, Кіренська) - низка філософських напрямів античності IV-III ст. до н. е., що базувалися на вченні Сократа і намагалися поставлені ним проблеми розв'язати за допомогою софістичних засобів. Наш інтерес до сократичних шкіл може бути виражений словами російського філософа О.Ф. Лосєва: «Они демонстрируют собою те логические возможности, которые возникали на почве сократовской философии» ${ }^{12}$. Г.В.Ф. Гегель, надаючи характеристику часу діяльності сократичних шкіл, писав: «Мы больше уже не видим, чтобы спрашивали и отвечали на вопрос, что такое природа, а спрашивают и отвечают на вопрос, что такое истина» ${ }^{13}$.

Мегарська школа (Евклід Мегарський, Евбулід Мілетський, Діодор Крон, Стільпон Мегарський та ін.). Мегарці заперечували будь-яке чуттєве пізнання. С.М. Трубецькой зазначає, що: «Исходной точкой мегарской философии, по-видимому, является сократовское требование логического знания, основанного на понятиях» ${ }^{14}$. Діоген Лаертський щодо учня Сократа, засновника мегарської школи Евкліда Мегарського (бл. 435/436-365 до н. е.) вказує: «Он заявлял, что существует одно только благо (agaton), лишь называемое разными именами: иногда разумением, иногда богом, а иногда умом и прочими наименованиями. А противоположное благу он отрицал, заявляя, что оно не существует» ${ }^{15}$. Представники мегарської школи додержувалися форм всезагальності та намагалася виявляти суперечності, що містяться в усіх одиничних уявленнях. За свідченням Діогена Лаертського, дещо подібне стверджував Стільпон Мегарський (бл. 360-280 до н. е.), який, слідуючи кінікам, доводив, що універсальне загальне поняття не може переноситися на будь-яке одиничне: «Он отвергал общие понятия (ta eidē). По его словам, кто говорит «человек», говорит «никто»: ведь это ни тот человек, ни этот человек (ибо чем тот предпочтительнее этого?) - а стало быть, никакой человек» ${ }^{16}$.

\footnotetext{
12 История античной эстетики. Софисты. Сократ. Платон. Москва : ООО «Издательство АСТ»; Харьков : Фолио, 2000. С. 96.

13 Гегель Г.В.Ф. Сочинения. Т. 10. Лекции по истории философии. Кн. 2. Москва : Партиздат, 1932. Институт Маркса - Энгельса - Ленина при ЦК ВКП(б). С. 90.

14 Трубецкой С.Н. История древней философии. Москва, 1906. Ч. І. С. 191.

15 Диоген Лаэртский. О жизни, учениях и изречениях знаменитых философов / ред. тома и авт. вступ. ст. А.Ф. Лосев ; перевод М.Л. Гаспарова. Москва : Мысль, 1986. С. 125.

16 Там само. С. 128.
} 
Кінічна школа (Антисфен Афінський, Діоген Синопський, Кратет Фіванський та ін.) синтезувала у собі багато ідей попередніх філософських вчень - Геракліта, Демокріта, елейців, софістів і Сократа. Погляди кініків базувалися на приматі чуттєвої дійсності та життєвого процесу над розумом. Розум ними формалізувався, схематизувався та перетворювався на абстрактний принцип. Діоген Лаертський вказує, що Діокл приписує засновнику школи кініків Антисфену Афінському (бл. 435-370 до н. е.) таке твердження: «Разумение - незыблемая твердыня: ее не сокрушить силой и не одолеть изменой. Стены ее должны быть сложены из неопровержимых суждений» ${ }^{17}$. Такий розум, позбавлений будь-якого реального змісту, перетворював життєві ідеї у непов'язані між собою одиничності, що призводило до заперечення логіки та переходу до номіналізму. Кінічна логіка, враховуючи засновки елейців, доходила висновку, що неіснуючого, а також неправильного не можна ні мислити, ні висловити, як і не можна собі суперечити. Виходячи із вчення Геракліта, кініки вважали, що сутність речей міститься в їхніх назвах, оскільки лише останні можуть виразити всеосяжну реальність одиничного у певний момент, нічого не додаючи i нічого не віднімаючи: «Рассмотрение слов - начало образования» ${ }^{18}$. Поняття розуміється лише як словесне позначення тієї чи іншої одиничності, яка реально або була, або $є$ тепер. Згідно із Діогеном Лаертським Антисфен дав перше визначення поняттю: «Понятие есть то, что раскрывает, что есть или чем бывает предмет» ${ }^{19}$. Аристотель писав, що прибічники Антисфена висловили: «Сомнение относительно того, можно ли дать определение сути вещи, ибо определение - это-де многословие, но какова вещь - это можно действительно объяснить» ${ }^{20}$. Теорія пізнання представників кінічної школи виступала проти платонівського вчення про ідеї: «Когда Платон рассуждал об идеях и изобретал названия для «стольности» и «чашности», Диоген сказал: «А я вот, Платон, стол и чашу вижу, а стольности и чашности не вижу». А тот: «И понятно: чтобы видеть стол и чашу, у тебя есть глаза, а чтобы видеть стольность и чашность, у тебя нет разума»»" ${ }^{21}$. В основі всього пізнання

17 Диоген Лаэртский. О жизни, учениях и изречениях знаменитых философов / ред. тома и авт. вступ. ст. А.Ф. Лосев ; перевод М.Л. Гаспарова. Москва : Мысль, 1986. С. 216.

18 Беседы Эпиктета / изд. подгот. Г.А. Таронян. Москва : Ладомир, 1997. С. 69.

19 Диоген Лаэртский. О жизни, учениях и изречениях знаменитых философов / ред. тома и авт. вступ. ст. А.Ф. Лосев ; перевод М.Л. Гаспарова. Москва : Мысль, 1986. С. 215.

20 Аристотель. Сочинения : в 4 т. Т. 1 / ред. В.Ф. Асмус. Москва : «Мысль», 1976. С. 228.

21 Диоген Лаэртский. О жизни, учениях и изречениях знаменитых философов / ред. тома и авт. вступ. ст. А.Ф. Лосев ; перевод М.Л. Гаспарова. Москва : Мысль, 1986. С. 230. 
у кініків визнаються лише одиничні чуттєві сприйняття та заперечується можливість виведення будь-яких узагальнень. Проте слід погодитися із важливим зауваженням О.Ф. Лосєва: «Киники не имеют логического права пользоваться даже простыми словами, потому что каждое слово есть уже обобщение» ${ }^{22}$. Таким чином, мудрець-кінік почувається вільним щодо суспільства: він бачить суспільні забобони, зневажає суспільний поголос, байдуже ставиться до держави, його не зв'язують ні звичаї, ні закони. Так, Діоген Лаертський наводить слова Антисфена: «В общественной жизни мудрец руководится не общепринятыми законами, а законами добродетели» ${ }^{23}$.

Кіренська школа (Арістіпп Кіренський, Гегесій, Евгемер, Феодор Кіренський та ін.). Кіренаїки визнавали, що речі існують поза свідомістю людини, але вони непізнавані, людям доступні лише відчуття цих речей. На відміну від кініків, кіренаїки на перший план висунули не розум, а чуттєвість. У них не «задоволення» підкорялося «благу», а останнє стало підкореним «задоволенню» та метою життя. Діоген Лаертський вказує, що Арістіпп Кіренський (бл. 435-355 до н. е.), учень Сократа, засновник Кіренської школи, на питання, чим філософи перевершують інших людей, відповів: «Если все законы уничтожатся, мы одни будем жить по-прежнему» ${ }^{24}$. Він вважав нікчемним той вчинок, який загалом тягне за собою більше незадоволення, ніж задоволення, і на цій підставі пропонував загалом підкорення звичаю та закону. Згідно із Арістіппом у викладенні Секста Емпірика нам відомі лише власні відчуття, які визначаються виключно почуттям задоволення чи незадоволення, але ніяк не об'єктивним предметом, про який ми нічого не знаємо. Проте у вченні кіренаїків наявні риси дуалізму. Так, за свідченням Діогена Лаертського, у представників кіренської школи чуттєві сприйняття не завжди є істинними: «Разумение, по их мнению, есть благо, ценное не само по себе, а лишь благодаря своим плодам. <..> Страсти постижимы, но причины их непостижимы. Физика отвергается, ибо природа явно непостижима, но логика признается, ибо она приносит пользу. $<\ldots>$ Нет ничего справедливого, прекрасного или безобразного по природе: все это определяется установлением и обычаем. <... Они

22 История античной эстетики. Софисты. Сократ. Платон. Москва : ООО «Издательство АСТ»; Харьков : Фолио, 2000. С. 228.

23 Диоген Лаэртский. О жизни, учениях и изречениях знаменитых философов / ред. тома и авт. вступ. ст. А.Ф. Лосев ; перевод М.Л. Гаспарова. Москва : Мысль, 1986. С. 218.

24 Там само. С. 113. 
учат, что один человек страдает больше, чем другой, и что ощущения иногда обманывают» ${ }^{25}$.

Розглянуті сократичні школи по-різному використовували сократівські принципи, намагалися їх синтезувати із софістикою, створюючи нові конфігурації понять. Якщо мегаріки зосередилися на раціональному і знехтували матеріальним, то кініки та кіренаїки на перший план висунули матеріальну стихію життя порівняно з ії раціональним обгрунтуванням. У майбутньому на грунті вчень мегарської та кінічної шкіл виріс стоїцизм, а на грунті філософії кіренської школи постав епікуреїзм.

\section{2. Платон і теорія пізнання}

Про особливості мислення у поняттях Г.В.Ф. Гегель писав: «Дело уже не столько в мыслях. У нас их достаточно, хороших и плохих, прекрасных и смелых. Дело в понятиях. Но если мысли должны приобрести непосредственную значимость благодаря самим себе, то в качестве понятий, напротив, они должны быть сделаны понятными. Форма слога от этого меняется и начинает требовать напряжения, быть может мучительного, как, например, у Платона и Аристотеля» ${ }^{26}$.

Сократ уперше зіткнувся із тим, що слова та поняття потребують глибокого дослідження, що у них є істотна та неістотна сторони. Прагнення давньогрецького філософа до точних визначень явищ морального життя потребувало як діалектичного мистецтва поділу за родами, так і вміння за багатозначністю слів розкривати постійний зміст, вбачати загальне у тому, що розрізнюється, єдине (одне) у множині, сутність у ії проявах. Учень Сократа Ксенофонт Афінський (бл. 430-355 до н. е.), писав про вчителя: «Да и слово «диалектика», говорил он, произошло оттого, что люди, совещаясь в собраниях, разделяют предметы по родам» ${ }^{27}$. Сократ визначив, що відмінною ознакою, яка відрізняє окремі гадки від істинного знання, $є$ існування останнього у загальних поняттях. Проте він не обгрунтував об’єктивної підстави такого висновку. Це питання було розв'язане його учнем Платоном. У діалозі «Тімей» Платон говорить: «Представляется мне, что для начала должно разграничить вот какие две вещи: что есть вечное, не имеющее возникновения бытие и что есть вечно возникающее, но никогда

\footnotetext{
25 Диоген Лаэртский. О жизни, учениях и изречениях знаменитых философов / ред. тома и авт. вступ. ст. А.Ф. Лосев ; перевод М.Л. Гаспарова. Москва : Мысль, 1986. С. 120.

26 Гегель. Работы разных лет : в 2 т. Т. 2 / сост., общая ред. А.В. Гулыги. Москва: «Мысль», 1973. С. 547.

27 Ксенофонт. Воспоминания о Сократе. Москва : Изд-во «Наука», 1993. С. 141.
} 
не сущее. То, что постигается с помощью размышления и рассуждения, очевидно, и есть вечно тождественное бытие; а то, что подвластно мнению и неразумному ощущению, возникает и гибнет, но никогда не существует на самом деле» ${ }^{28}$. Він виходить із того, що, оскільки явища, які нас оточують, є доступними нашому чуттєвому сприйняттю, вони створюють світ відносної дійсності мінливих і скороминущих речей. За допомогою чуттєвого сприйняття ми через зовнішні скороминущі явища пізнаємо мінливий світ речей і формуємо про нього окремі гадки. Платон припустив, що існує інший світ, світ істинної дійсності, який складається із загальних незмінних ідей, що утворюють зміст понять, які виражають незмінне, вічне буття. Припущення про існування ідей як онтологічно первинних і самодостатніх загальних понять призвело до дискусії між Платоном і представниками сократичних (мегарської, кінічної та кіренської) шкіл. Якщо кіренаїки сутністю вважали відношення сущого до єдиної свідомості, а кініки вбачали сутність у безпосередній свободі, то Платон, навпаки, сутністю вважав пізнання. Теорії пізнання сократичних шкіл він піддав критиці у діалозі «Теетет». Проте перед Платоном постали нові запитання: як пояснити світ ідей у їхній множинності та в їхньому різноманітті? Як пояснити відношення чуттєвих речей до їхніх ідей? Яким чином ідеї співвідносяться між собою та як вони співвідносяться з речами? У діалогах, написаних у різний час, Платон наводить декілька різних відповідей. Він доходить висновку, що істинне пізнання відбувається у поняттях, тому воно має бути пізнанням буття: «Нам в наших поисках нужно отправляться не от знания или незнания, но от бытия или небытия» ${ }^{29}$. Таким чином, речі дійсності, що нас оточує, не можуть дати істинного пізнання ідей, оскільки вони є лише відображеннями ідей. У зв’язку із тим, що явища чуттєвого світу $\epsilon$ тільки відображеннями ідей, останні є їхньою причиною. Оскільки ідеї незмінні й непорушні, вони виступають не як рушійна причина, а як мета, що до себе притягає. Співвідношення між явищем та ідеєю $є$ телеологічним: «Однако все возникающее должно иметь какую-то причину для своего возникновения, ибо возникнуть без причины совершенно невозможно. Далее, если демиург любой вещи взирает на неизменно сущее и берет его в качестве первообраза при создании идеи и свойств

28 Платон. Собрание сочинений : в 4 т. Т. 3 / пер. с древнегреч. ; общ. ред. А.Ф. Лосева, В.Ф. Асмуса, А.А. Тахо-Годи ; Авт. вступ. ст. и ст. в примеч. А.Ф. Лосев ; примеч. А.А. Тахо-Годи. Москва : Мысль, 1994. С. 432.

29 Платон. Собрание сочинений : в 4 т. Т. 2 / общ. ред. А.Ф. Лосева, В.Ф. Асмуса, А.А. Тахо-Годи ; примеч. А.Ф. Лосева и А.А. Тахо-Годи ; пер. с древнегреч. Москва : Мысль, 1993. C. 247. 
данной вещи, все необходимо выйдет прекрасным; если же он взирает на нечто возникшее и пользуется им как первообразом, произведение его выйдет дурным» ${ }^{30}$.

У діалозі «Кратіл», присвяченому найменуванню речей і встановленню імен, Платон в особі Сократа відводить праву засадниче місце, підкреслюючи його верховенство, та зазначає: «Что же до «справед-

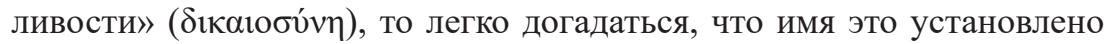

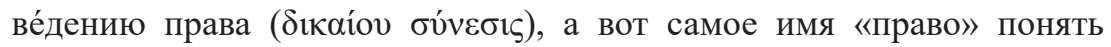
трудно. Видимо, дело в том, что до некоторого предела почти все единодушны, а вот дальше начинаются разногласия. Те, кто считает, что все находится в пути, полагают также, что большая часть вещей просто движется, а есть еще нечто такое, что проникает все остальное, благодаря чему и возникает все рождающееся. <...> Следовательно,

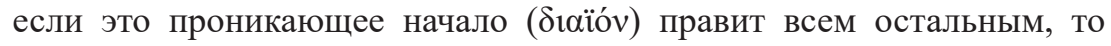

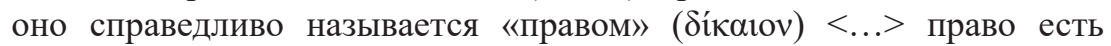
то же, что и причина (aítiov), ведь то, что правит возникновением вещей, это же одновременно и их причина <..> право - это ум, как указывает Анаксагор, ибо ум, независимый и ни с чем не смешанный, все упорядочивает, проникая все вещи» ${ }^{31}$. Як слушно зауважив доктор Джейкоб Ейслер: «If, as Alfred North Whitehead quipped, all philosophy is a footnote to Plato, then the Laws has proven the most troubling subject for such footnoting» ${ }^{32}$ («Якщо, як сказав Альфред Норт Вайтгед, вся філософія є приміткою до Платона, то закони виявилися найбільш тривожною темою для таких приміток»- Д. К., Л. Г.). Платон, надаючи особливого значення знанню про закони, звертає увагу на співзвучність грецьких слів «закон» і «розум»: «Ведь из всех наук более всего совершенствует человека, ими занимающегося, наука о законах; по крайней мере так должно быть, если правильны ее положения, ведь не напрасно божественный и чудесный закон (vó $\mu$ ऽ) получил бы у нас название, близкое к слову «ум» $\left(\right.$ vóos)»» ${ }^{33}$. У діалозі «Політик» він визначає закони як «подражания истине вещей» ${ }^{34}$, а у діалозі «Закони»

30 Платон. Собрание сочинений : в 4 т. Т. 3 / пер. с древнегреч. ; общ. ред. А.Ф. Лосева, В.Ф. Асмуса, А.А. Тахо-Годи. Москва : Мысль, 1994. С. 432.

31 Платон. Собрание сочинений : в 4 т. Т. I / общ. ред. А.Ф. Лосева и др. Москва : Мысль, 1990. C. $648-649$.

32 Jacob Eisler. Plato's Pragmatic Project: A Reading of Plato's Laws. By Myrthe L. Bartels / The Cambridge Law Journal. Cambridge, March 2018. Vol. 77, Issue 1. P. 223.

33 Платон. Собрание сочинений : в 4 т. Т. 4 / пер. с древнегреч. ; общ. ред. А.Ф. Лосева, В.Ф. Асмуса, А.А. Тахо-Годи. Москва : Мысль, 1994. С. 423.

34 Там само. С. 55. 
вказує, що законом необхідно іменувати певні «определения разума» ${ }^{35}$ (співзвучні грец. nómos - закон i dianomh - букв. розділення, установлення; у цьому перекладі - «визначення» - Д. К., Л. Г.). У діалозі «Держава» Платон вказує: «У кого началом служит то, чего он не знает, а заключение и середина состоят из того, что нельзя сплести воедино, может ли подобного рода несогласованность когда-либо стать знанием? <..> Значит, в этом отношении один лишь диалектический метод придерживается правильного пути» ${ }^{36}$. Ідеї пізнаються діалектичним методом: «Когда же кто-нибудь делает попытку рассуждать, он, минуя ощущения, посредством одного лишь разума устремляется к сущности любого предмета и не отступает, пока при помощи самого мышления не постигнет сущности блага (найвища ідея у Платона Д. К., Л. Г.). Так он оказывается на самой вершине умопостигаемого, подобно тому, как другой взошел на вершину зримого» ${ }^{37}$. О.Ф. Лосєв зазначає: «Платоновская идея есть родовое понятие, то есть обобщение отдельных вещей и их групп, и, следовательно, имеет дело не с вещами, но с логическими абстракциями. <...> Платоновская идея не есть просто обобщение вещей и предметов, но предельное обобщение, то есть такое обобщение, дальше которого уже делается невозможным самый процесс абстрагирования» ${ }^{38}$. Таким чином, і сьогодні залишаються актуальними слова М. Хайдеггера про те, що: «All metaphysics, including its opponent, positivism, speaks the language of Plato $)^{39}$ ( $\ll \mathrm{Bc}$ метафізика, включно з їі опонентом, позитивізмом, говорить мовою Платона» - Д. К., Л. Г.).

У діалозі «Федр» Платон вводить методи «синагоги» та «діарези», що передбачають вміння «охватывая все общим взглядом, возводить к единой идее то, что повсюду разрозненно, чтобы, давая определение каждому, сделать ясным предмет поучения», i «наоборот, способность разделять всё на виды, на естественные составные части, стараясь при этом не раздробить ни одной из них» ${ }^{40}$. «Синагога» (грец. synagoge -

35 Платон. Собрание сочинений : в 4 т. Т. 4 / пер. с древнегреч. ; общ. ред. А.Ф. Лосева, В.Ф. Асмуса, А.А. Тахо-Годи. Москва : Мысль, 1994. С. 165.

36 Платон. Собрание сочинений в 4 т. Т. 3 / пер. с древнегреч. ; общ. ред. А.Ф. Лосева, В.Ф. Асмуса, А.А. Тахо-Годи. Москва : Мысль, 1994. С. 317.

37 Там само. С. 316.

38 Лосев А.Ф. История античной эстетики. Софисты. Сократ. Платон. Москва : ООО «Издательство АСТ»; Харьков : Фолио, 2000. С. 184.

39 Heidegger M. The End of Phifosophy and the Task of Thinking in Basic Writings. London, Routledge, 1993. Р. 444.

40 Платон. Собрание сочинений : в 4 т. Т. 2 / общ. ред. А.Ф. Лосева, В.Ф. Асмуса, А.А. Тахо-Годи. Москва, 1993. С. 176. 
букв. зібрання) - метод піднесення до єдиної ідеї роз'єднаного у множині одиничних речей. «Дієреза» або «дієрезис» (грец. diairesis - букв. ділення, розрізнення) - метод розділення, що дозволяє виділяти вид i давати йому визначення шляхом дихотомічного членування роду та відрізняти види один від одного. Так, у діалозі «Теетет», відшукуючи визначення поняття «знання», Платон переходить від загальної ідеї до відмінної ознаки: «Если подметить отличительный признак отдельной вещи - чем она отличается от прочих вещей, - тем самым, как говорят некоторые, можно найти объяснение этой вещи? А пока ты касаешься только общего, у тебя будет объяснение лишь того, что обще вещам» ${ }^{41}$. Згодом ця робота стала основою для створення Аристотелем учення про форми мислення: поняття, судження й умовивід (силогізм). Особливого значення діалектика набуває у контексті онтологічних побудов Платона, що виступає вже не як мистецтво розмови, а як мистецтво правильного мислення, яке полягає в умінні оперувати поняттями з метою визначення сутності будь-якої речі.

\section{3. Теорія ідей Платона}

Учень Сократа Платон (427-347 або 348 рр. до н. е.) намагався досягнути істинного знання про сутність речей шляхом, вказаним Сократом, - пізнанням за допомогою понять, який він назвав діалектикою (грец. dialektiké (techné) - мистецтво вести бесіду, суперечку). Метою діалектики за Платоном, з одного боку, є відшукання окремих понять (грец. synagoge - зібрання): «Но ты не станешь все валить в одну кучу, рассуждая разом и об исходном понятии, и о его следствиях» $»^{42}$. 3 іншого боку - встановлення відношень між ними шляхом ділення (грец. diaeresis - ділення): «Не только большое никогда не согласится быть одновременно и большим и малым, но и большое в нас никогда не допустит и не примет малого, не пожелает оказаться меньше другого. <..> Так же точно и малое в нас никогда не согласится стать или же быть большим, и вообще ни одна из противоположностей, оставаясь тем, что она есть, не хочет ни превращаться в другую противоположность, ни быть ею, но либо удаляется, либо при этом изменении гибнет» ${ }^{43}$. Поняття не можуть належати до чуттєвих речей, а реальним предметом понять $є$ речі, осяжні розумом, які Платон назвав

\footnotetext{
41 Платон. Собрание сочинений : в 4 т. Т. 2 / общ. ред. А.Ф. Лосева, В.Ф. Асмуса, А.А. Тахо-Годи. Москва, 1993. С. 272.

42 Там само. С. 61.

43 Там само. С. 62.
} 
iдеями (iдея - грец. idea). Діоген Лаертський вказує: «Платон в своем учении об идеях говорит так: идеи присутствуют во всем, что есть, ведь существует память, память бывает лишь о вещах покоящихся и пребывающих, а пребывают лишь идеи, и ничто другое. <..> А как об этом пишет Эпихарм? <..> Нет на всех единой мудрости, но есть во всем живом свое понятие» ${ }^{44}$. О.Ф. Лосєв зазначає: «Платоновская идея есть логическое понятие, содержащее в себе предельно-обобщенное; принции и метод, порождающую модель, или, вообще говоря, причину осмысления каждой вещи» ${ }^{45}$. В одному із ранніх діалогів Платона «Євтифрон» (399 р. до н. е.) Сократ постає перед читачем у період, що безпосередньо передує судовому процесу над ним. Сократ щойно дізнався, що якийсь Мелет подав на нього донос, у якому він обвинувачується у поганому впливі на молодь і зневірі у вітчизняних богів. У приміщенні, де засідав архонт-базилевс, Сократ зустрічає Свтифрона - офіційного афінського віщуна, що подав позов на рідного батька, котрий мимоволі став причиною смерті найманого працівника. Свтифрон вважає, що діє достатньо благочестиво, а Сократ приходить на суд як жертва доносу, звинувачений у нечесті. Виникає запитання, що ж тоді є благочестя? На початку діалогу Євтифрон у приватній бесіді із Сократом говорить, що не прислухається до гадки натовпу, оскільки останній не знає, чим є благочестя: «А ведь они просто плохо знают божественный закон, касающийся благочестия и нечестия» ${ }^{46}$. Сократ запитує: «Скажи, ради Зевса, Евтифрон, ты-то себя считаешь настолько точно осведомленным в божественных законах и в вопросах благочестия и нечестия $<\ldots>$ ? < . .> Разве же в любом деле благочестивое не тождественно самому себе, и, с другой стороны, разве нечестивое не противоположно всему благочестивому, самому же себе подобно, и разве не имеет оно некоей единственной идеи, выражающей нечестие для всего, что по необходимости бывает нечестивым?» ${ }^{47}$ (перша поява терміна «ідея» на позначення філософського поняття у західній традиції - Д. К., Л. Г.). Благочестя тотожне саме собі та протилежне нечестю, тоді як нечестя тотожне саме собі та протилежне благочестю. Виникають два філософські поняття - тотожність

44 Диоген Лаэртский. О жизни, учениях и изречениях знаменитых философов / ред. тома и авт. вступ. ст. А.Ф. Лосев ; перевод М.Л. Гаспарова. Москва : Мысль, 1986. С. 140-141.

45 Лосев А.Ф. История античной эстетики. Софисты. Сократ. Платон. Москва : ООО «Издательство АСТ»; Харьков : Фолио, 2000. С. 187.

46 Платон. Собрание сочинений : в 4 т. Т. 1 / общ. ред. А.Ф. Лосева и др. Москва : Мысль, 1990. C. 298.

47 Там само. С. 298-299. 
і протилежність, що можна розуміти тільки на підставі ідей. Коли у нас $€$ ідея «благочестя», ми можемо визначити благочестиві вчинки, коли ж ми маємо ідею «нечестя», то можемо дати визначення нечестивим вчинкам. Тобто Сократ говорить до Свтифрона: якщо ти покажеш мені ідею «благочестя», то мені буде легше виправдатися перед Мелетом, оскільки я доведу йому, що мій вчинок був благочестивим. Далі Сократ запитує у Свтифрона: «Так скажи же, что именно ты называешь благочестивым и нечестивым?» ${ }^{48}$. Свтифрон відповідає: «Я утверждаю: благочестиво то, что я сейчас делаю, а именно благочестиво преследовать по суду преступника, совершившего убийство, либо ограбившего храм, либо учинившего еще какое-нибудь подобное нарушение <...>; не преследовать же по суду в таких случаях - нечестиво» ${ }^{49}$ (перше визначення благочестя та нечестя через окремі визначення - Д. К., Л. Г.). Сократ уточнює запитання: «Так припомни же, что я просил тебя не о том, чтобы ты назвал мне одно или два из благочестивых деяний, но чтобы определил идею как таковую (тут ідея - грец. eidos Д. К., Л. Г.), в силу которой все благочестивое является благочестивым. Ведь ты подтвердил, что именно в силу единой идеи нечестивое является нечестивым, а благочестивое - благочестивым. <..> Так разъясни же мне относительно этой идеи, что именно она собой представляет, дабы, взирая на нее и пользуясь ею как образцом (взірець грец. paradeigma - Д. К., Л. Г.), я называл бы что-либо одно, совершаемое тобою либо кем-то другим и подобное этому образцу, благочестивым, другое же, не подобное ему, таковым бы не называл» ${ }^{50}$. Сократа не цікавить окрема гадка Євтифрона про те, що таке «благочестя», його цікавить те, що є «благочестям» взагалі. Отже, Платон використовує термін «ідея» в аспекті понять «тотожність», «протилежність», «взірець». Далі Євтифрон відповідає: «Итак, благочестиво то, что угодно богам, нечестиво же то, что им неугодно» ${ }^{51}$ (друге визначення благочестя та нечестя шляхом переходу від окремого до загального - Д. К., Л. Г.). Сократ продовжує: «Угодное богам и угодный им человек - это благочестивые вещи, а неугодное богам и неугодный им человек - нечестивые, и, значит, благочестивое и нечестивое не тождественны между собою, а прямо противоположны друг другу.

\footnotetext{
48 Платон. Собрание сочинений : в 4 т. Т. 1 / общ. ред. А.Ф. Лосева и др. Москва : Мысль, 1990. C. 299.

49 Там само. С. 299.

50 Там само. С. 300-301.

51 Там само. С. 301.
} 
Не так ли?» ${ }^{52}$. Свтифрон погоджується. Далі Сократ і Свтифрон доходять спільного висновку, що у богів є розбіжності, тому вони сперечаються. Сократ продовжує: «А среди богов, благороднейший Евтифрон, одни, по твоим словам, почитают одно справедливым, прекрасным, постыдным, добрым и злым, а другие - другое: ведь не восставали бы они друг на друга, если бы не спорили из-за этого. <.. > Но, Евтифрон, согласно этому рассуждению, благочестивое и нечестивое - это одно и то же ${ }^{53}$. Далі Сократ звертається до Свтифрона: «Итак, я освобождаю тебя от этого, Евтифрон: пусть, коли тебе угодно, все боги считают это противозаконным и ненавидят. Но давай внесем сейчас такую поправку в рассуждение: нечестиво ненавистное всем богам, а угодное всем им - благочестиво, если же что-либо одни из них любят, а другие ненавидят, то это либо ни то ни другое, либо и то и другое одновременно» ${ }^{54}$. Свтифрон погоджується: «Но и я бы назвал благочестивым то, что любят все боги, и, наоборот, нечестивым то, что все они ненавидят» ${ }^{55}$ (третє визначення благочестя та нечестя через узагальнення - Д. К., Л. Г.). Далі Сократ запитує: «Благочестивое любимо богами потому, что оно благочестиво, или оно благочестиво потому, что его любят боги? <...> Ну вот, не думаешь ли ты, что все благочестивое необходимо должно быть справедливым?» ${ }^{56}$. Свтифрон погоджується. Тоді Сократ запитує: «Значит, и все справедливое должно быть благочестивым или же все благочестивое будет справедливым, справедливое же не всё будет благочестивым, но в одних случаях будет, а в других нет?» ${ }^{57}$ (у західній традиції вперше виникає класифікація понять). Євтифрон погоджується із Сократом, що благочестя є частиною справедливості. Далі Сократ звертається до Свтифрона: «Вот и постарайся таким образом разъяснить мне, какою частью справедливого будет благочестивое» ${ }^{58}$. Свтифрон відповідає: «Итак, Сократ, мне представляется, что праведным и благочестивым является та часть справедливого, которая относится к служению богам; та же, что относится к заботе о людях, будет остальною частью справедливого» ${ }^{59}$ (четверте

\footnotetext{
52 Платон. Собрание сочинений : в 4 т. Т. 1 / общ. ред. А.Ф. Лосева и др. Москва : Мысль, 1990. C. 301.

53 Там само. С. 302.

54 Там само. С. 304.

55 Там само. С. 304-305.

56 Там само. С. $305,307$.

57 Там само. С. 307-308.

58 Там само. С. 309.

59 Там само. С. 309.
} 
визначення благочестя через визнання його частиною иілого - Д. К., Л. Г.). Сократ запитує Євтифрона: «Так, значит, и благочестие, будучи заботой о богах, приносит богам пользу и делает их лучшими?» ${ }^{60}$. Євтифрон заперечує, оскільки боги є досконалими, їх не можна покращити. Тоді Сократ запитує: «Но тогда что же это такое, Евтифрон, наши дары богам?» ${ }^{61}$. Свтифрон відповідає, що це почесні нагороди людей, приємні богам. Сократ запитує: «Значит, Евтифрон, благочестивое - это приятное, а не полезное и угодное богам?» ${ }^{62}$. Свтифрон відповідає: «Думаю, что, несомненно, это угодное им» ${ }^{63}$. Сократ підсумовує: «Значит, вот оно что такое, благочестивое, - это угодное богам. $<. .>$ Значит, либо мы недавно пришли к неправильному решению, либо, если тогда мы решили правильно, то сейчас мы не правы. <..> Следовательно, нам надо с самого начала пересмотреть, что такое благочестивое» ${ }^{64}$. Проблема ейдосів (діалектики родо-видових відношень) ставиться Платоном у період його пізньої творчості у діалозі «Парменід» і розв'язується ним у діалозі «Софіст». Термінологічні зауваги до діалогу «Парменід». У наявних перекладах із грецької незадовільним $€$ те, що в оригінальному тексті відсутнє слово «річ». Платон на позначення множини у діалозі використовує грецькі терміни «pollá» - «багато» та «pánta» - «усе». У творі під час розмови між Сократом і Парменідом про сутність ейдосів, які мають бути відокремлені від «речей» (від «багатьох» - Д. К., Л. Г.) з'ясовується, що існує два рівні ейдосів. На рівні чуттєвого сприйняття у таких сутностей як людина, вода, вогонь тощо $є$ ейдоси. Також ейдоси $є$ на рівні мисленого сприйняття, наприклад, у таких сутностей, як добро, справедливість і т. ін. У понятті «лодла́⿱亠 поєднуються два види ейдосів, по-перше, належних сутностям чуттєвого сприйняття, тобто речам, по-друге, належних сутностям мисленого сприйняття, тобто загальним поняттям. Таким чином, у Платона ще не відокремлені ейдоси сутностей чуттєвого сприйняття від ейдосів сутностей мисленого сприйняття. Платон у діалозі розрізняє «ейдос» (грец. eidos) та «ідею» (грец. idéa). Як вбачається зі змісту діалогу, ідеї є ейдосами чистого мислення, тобто ейдосами загальних понять.

\footnotetext{
${ }_{60}$ Платон. Собрание сочинений : в 4 т. Т. 1 / общ. ред. А.Ф. Лосева и др. Москва : Мысль, 1990. C. 310.

61 Там само. С. 312.

62 Там само. С. 312.

63 Там само. С. 312.

64 Там само. С. 312-313.
} 
На початку діалогу «Парменід» намічаються дві логічні лінії. Перша - позиція «Парменіда - Зенона», згідно з якою є деяке «одне», що протистоїть «множині». «Одне»є (Парменід), а «множини» немає (Зенон). Стверджується, що світ можна поділити на «є» (шлях сущого) та «немає» (шлях не сущого). Проте «немає» є неспроможним, оскільки небуття немає, тобто не сущого просто немає. Таким чином, світ «є», тобто $є$ сущим. Але Парменід розуміє, що у світі $є$ i «множина» сущих, яку ми спостерігаємо. Незважаючи на те, що ми спостерігаємо «множину» сущих, Парменід в обгрунтування того, що $є$ «одне», виходить із того, що сущі (суще 1 , суще 2 i т. д.) між собою змикаються в одне ціле в аспекті буття, оскільки між ними немає і бути не може небуття. «Одне» не дається нам у чуттєвому сприйнятті, в якому нам дається лише «множина». Проте постає питання, як підтвердити, що «одне», яке ми лише мислимо, є, коли ми самі у ньому перебуваємо. Для цього Парменід звертається до формули «бути і мислити одне і те ж», яка означає, що якщо «одне» мислиться, то воно і «є». Таким чином, відбувається перехід від «одного», що нами мислиться, до «одного», що «є» (грец. en einai - букв. одне «бути»; одне є). У Парменіда виникає дилема між «одним» $\mathrm{i}$ «множиною», розрізнення між якими відбувається через розрізнення мислення та чуттєвого сприйняття. Друга - позиція «Сократа», якою заперечується позиція «Парменіда Зенона». Сократ стверджує, що між «одним» і «множиною» відсутня суперечність. В обгрунтування цього він зазначає, що, коли, наприклад, «одне» - людина, причетна до ейдосу «одного», то вона $є$ чимось одним, а коли вона причетна до ейдосу «множини», вона одночасно є чимось множинним. Сократ говорить: «Пусть-ка кто докажет, что единое, взятое само по себе, есть многое и, с другой стороны, что многое [само по себе] есть единое, вот тогда я выкажу изумление. И по отношению ко всему другому дело обстоит так же: если бы было показано, что роды и виды испытывают сами в себе эти противоположные состояния, то это было бы достойно удивления» ${ }^{65}$. Із цього випливає, що існує багато ейдосів, і вони відокремлені від сущих. Перше міркування. $Є$ ейдос (множина ейдосів), до якого приєднується «множина» (грец. «pollá», «pánta»). 3 іншого боку, цей ейдос є чимось «одним» (грец. kath hauto - букв. сам по собі). Висувається перша гіпотеза ейдос $\epsilon$ чимось, що чуттєво сприймається, тобто речовим, оскільки перебуває усередині кожної речі (грец. en pasin - у всьому). Друга

${ }_{65}$ Платон. Собрание сочинений : в 4 т. Т. 2 / общ. ред. А.Ф. Лосева, В.Ф. Асмуса, А.А. Тахо-Годи. Москва, 1993. С. 349. 
гіпотеза - ейдос є чимось просторовим, тобто може бути подільним. Проте ці гіпотези є безпідставними, призводять до суперечностей, оскільки ейдос розглядається як «одне» і «множина» одночасно. Друге міркування. Ейдос $є$ чимось мисленим. Перша гіпотеза - ейдос є ідея (грец. idéa). Коли ми дивимося на такі «множини», як добро, справедливість, нам у них здається певна ідея. Платон грецьке дієслово dokéo (здаватися) використовує у значенні «думати, гадати на рівні мисленого сприйняття», а phaeínō (здаватися) - у значенні «відкривати, являтися, вбачати на рівні чуттєвого сприйняття». Коли ж ми у вказаних «множинах» прозріваємо дещо «одне», то ці «множини» разом із цим «одним» дадуть нам нове «одне», оскільки ейдоси чуттєвого та мисленого нами ще не розрізняються. Це призводить до суперечності у зв'язку із тим, що ейдос $є$ «одне» і «множина» одночасно. Друга гіпотеза - ейдос є думка (грец. по́е̄ma), що виникає всередині душі. Ця думка є думкою про певну ідею, а оскільки бути і мислити одне і те саме, то вона є думкою про сущу ідею (грец. mia ousia idéa). Таким чином, ейдос є мислиме «одне» суще саме по собі над усім:

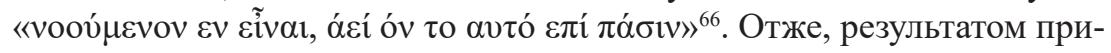
єднання «множини» до ейдоса буде одна думка. Третя гіпотеза - ейдос є зразок. Чуттєвим ейдосам відповідають чуттєві зразки, а мисленим ейдосам - мислені зразки. Чуттєві зразки подібні між собою, і мислені зразки подібні між собою. Коли до ейдоса як зразка приєднуються подібні «множини», то ейдос уподібнюється «множинам», і вони тоді, як подібні між собою, є подібними чомусь третьому, що породжує збільшення ейдосів. Парменід звертається до Сократа: «Такие возражения кажутся основательными, а высказывающего их, как мы недавно сказали, переубедить необычайно трудно. И надо быть исключительно даровитым, чтобы понять, что существует некий род каждой вещи и сущность сама по себе» ${ }^{67}$. Таким чином, ідеї у Платона - це роди сущого (те, що ми сьогодні називаємо загальними поняттями), а ейдоси - це чуттєві образи. У діалозі «Парменід» Платон застосовує т. зв. гіпотетичний метод, відповідно до якого філософ у своєму міркуванні переходить від одного припущення (гіпотези) до іншого, використовуючи їх як своєрідні сходи.

У діалозі «Софіст» поняття «ейдос» (грец. eidos) стає більш конкретним, стає «видом», оскільки відокремлюється від поняття «рід»

${ }_{66}$ Платон. Собрание сочинений : в 4 т. Т. 2 / общ. ред. А.Ф. Лосева, В.Ф. Асмуса, А.А. Тахо-Годи. Москва, 1993. С. 353.

67 Там само. С. 357. 
(грец. genos). Поняття «ейдос» використовується для позначення чуттєвих (одиничних) образів. Для позначення загальних образів (загальних понять) використовується термін «рід». У Платона на верхівці перебувають «роди» (загальне). Кожен «рід» є «одним». До цих «родів» долучаються «види» (множина). Платон до «родів» відносить одиничні сутності чуттєвого (безпосереднього) сприйняття (людей, тварин тощо) та сутності мисленого сприйняття, тобто ідеї, що є деякими мисленнєвими аспектами (загальними поняттями). Таким чином, філософ ще не розрізняє «роди» одиничних сутностей та ідеї. Отже, те, що у діалозі «Парменід» Платон назвав «ейдосом», у діалозі «Софіст» він називає «родом». Надаючи визначення поняттю «софіст», він таким чином характеризує пошук відмінних (видових) ознак: «Попробуем-ка, снова разделяя на двое находящийся перед нами род, каждый раз держаться в пути правой части, имея в виду то, что относится к софисту, пока мы, пройдя мимо всего общего [между ним и другими видами] и оставив ему его собственную природу, не выставим ее напоказ прежде всего нам самим, а потом и тем, кто от природы близок такому методу исследования» ${ }^{68}$.

\section{ВИСНОВКИ}

Доба Сократа і Платона зумовлена постановкою гносеологічної проблеми - роздумами про сутність знання. Вони намагалися через пізнання сутності знання пізнати Істинне Благо. Сократ і Платон вважали, що недостатньо мати правильну гадку, необхідно прагнути до знання. Гадка (позірне знання) некорисна, якщо вона не обернена у знання за допомогою «міркування розуму». Встановлено, що, оскільки Сократ не запропонував єдиної системи мислення, сократичні школи, які мали різні погляди на його вчення, оспорювали сократівську проблематику, виходячи саме із софістичного способу мислення. Сократ займався питаннями моральності, шукав у ній загальне та звернув увагу на визначення. Він шукав моральні поняття - нормативні рішення, придатні для визначення цілей і цінностей морального життя. Платон переносить це на всі поняття. Філософ доходить висновку, що вираження поняття у мові - слово - може мати певну схожість зі змістом поняття, проте неспроможне передати його у всій його чистоті та повноті. Він зауважив, що визначення, на які звернув увагу Сократ, не належать чуттєвому сприйняттю, а належать іншому, котре він назвав ідеями. Знаходження цих ідей веде до набуття істинного знання й, у підсумку, до осягнення Вищого Блага. Розроблення теорії

68 Там само. С. 340. 
ідей, методів об'єднання розрізнених понять у єдине, дихотомічного ділення понять дозволило Платону відкрити поняття роду та виду, дослідити родо-видові відношення між поняттями. Саме із цього звернення до розуму, що мислить, до пошуку істини почалися європейська філософія та наука, у т. ч. і правова, у сучасному їх розумінні.

\section{АНОТАЦІЯ}

На прикладі «сократичного повороту», що відбувся у Давній Греції y V ст. до н. е., розкрито специфічні умови, які зумовили становлення у IV-III ст. ст. до н. е. нового мислення у поняттях, у т. ч. правового. Досліджено вчення Сократа про знання та поняття. Вказано, що саме Сократ уперше предметом знання назвав поняття, а способом побудови теоретичного знання шляхом формулювання та виведення понять визначив діалектичний метод науки. Ця лінія була продовжена учнем Сократа Платоном. Встановлено, що перехідною ланкою між Сократом і Платоном стали сократичні школи. Показано обгрунтування Платоном об'єктивної підстави для розмежування істинного знання від неістинного через існування ідей як онтологічно первинних і самодостатніх загальних понять. Зазначено, що Платон у своїй теорії пізнання причиною виникнення речей і началом, яке їх упорядковує, визначив право, а методом пізнання ідей (понять) - діалектичний метод.

\section{ЛІТЕРАТУРА}

1. Вебер М. Избранные произведения / пер. с нем. ; сост., общ. ред. и послесл. Ю.Н. Давыдова ; предисл. П.П. Гайденко. Москва : Прогресс, $1990.808 \mathrm{c}$.

2. Трубецкой С.Н. История древней философии. Москва, 1906. Ч. I. $211 \mathrm{c.}$

3. Аристотель. Сочинения : в 4 т. Т. 1 / ред. В.Ф. Асмус. Москва : «Мысль», 1976. 550 с.

4. Маркс К., Энгельс Ф. Из ранних произведений. Москва : Государственное издательство политической литературы. 1956. 699 с.

5. Платон. Сочинения : в 4 т. Т. 2 / под общ. ред. А.Ф. Лосева и В.Ф. Асмуса ; пер. с древнегреч. Санкт-Петербург : Изд-во С.-Петерб. ун-та: «Изд-во Олега Абышко», 2007. 626 с.

6. Ксенофонт. Воспоминания о Сократе. Москва : Изд-во «Наука», 1993. $379 \mathrm{c.}$

7. История античной эстетики. Софисты. Сократ. Платон. Москва : ООО «Издательство АСТ»; Харьков : Фолио, 2000. 846 с. 
8. Гегель Г.В.Ф. Сочинения. Т. 10. Лекции по истории философии. Кн. 2. Москва : Партиздат, 1932. Институт Маркса - Энгельса - Ленина при ЦК ВКП(б). 454 с.

9. Диоген Лаэртский. О жизни, учениях и изречениях знаменитых философов / ред. тома и авт. вступ. ст. А.Ф. Лосев ; перевод М.Л. Гаспарова. Москва : Мысль, 1986. 571 с.

10. Беседы Эпиктета. Москва : Ладомир, 1997. 312 с.

11. Гегель. Работы разных лет : в 2 т. Т. 2. Москва : Мысль, 1973. 630 с.

12. Платон. Собрание сочинений : в 4 т. Т. 3 / пер. с древнегреч.; общ. ред. А.Ф. Лосева, В.Ф. Асмуса, А.А. Тахо-Годи. Москва : Мысль, 1994. $654 \mathrm{c}$.

13. Платон. Собрание сочинений : в 4 т. Т. 2 / общ. ред. А.Ф. Лосева, В.Ф. Асмуса, А.А. Тахо-Годи. Москва : Мысль, 1993. 528 с.

14. Платон. Собрание сочинений : в 4 т. Т. 1 / общ. ред. А.Ф. Лосева и др. Москва : Мысль, 1990. 860 с.

15. Jacob Eisler. Plato's Pragmatic Project: A Reading of Plato's Laws / by Myrthe L. Bartels. The Cambridge Law Journal. Cambridge, March 2018. Vol. 77, Issue 1. P. 223-227.

16. Платон. Собрание сочинений : в 4 т. Т. 4 / пер. с древнегреч.; общ. ред. А.Ф. Лосева, В.Ф. Асмуса, А.А. Тахо-Годи. Москва : Мысль, 1994. $830 \mathrm{c}$.

17. Лосев А.Ф. История античной эстетики. Софисты. Сократ. Платон. Москва : ООО «Издательство АСТ»; Харьков : Фолио, 2000. 846 с.

18. Heidegger M. The End of Phifosophy and the Task of Thinking in Basic Writings. London, Routledge, 1993. P. 464.

\section{Information about authors:}

Kucherenko D. S., Legal counsel "COMREC LTD" 177-A, Culturna str., Zaporizhzhia, Ukraine Hamburh L. S.,

Candidate of Juridical Sciences (Ph. D. in Law Sciences), Associate Professor, Assistant Professor of Theory, History of State and Law and International

Law Department Classic Private University 70B, Zhukovsky str., Zaporizhzhia, Ukraine DOI https://doi.org/10.30525/978-9934-588-43-3/2.13 